\title{
PENGARUH KECERDASAN EMOSI TERHADAP EFIKASI DIRI DAN ADVERSITY QUOTIENT REMAJA
}

\author{
${ }^{1}$ Novia Fetri Aliza, ${ }^{2}$ Lia Oktafiani \\ 1,2Program Studi Komunikasi dan Konseling Islam, Fakultas Agama Islam, Universitas Muhammadiyah \\ Yogyakarta,Jalan Brawijaya, Geblagan, Tamantirto, Kasihan, Bantul, DIY, 55183, Indonesia.
} aliza@umy.ac.id.

\begin{abstract}
This research is aims to know the contribution of emotional intelligence to selfefficacy and adversity quotient of teenager. This research design is using a causal relationship study design. The subject of this study was the equivalent of 60 in junior high school. Data is collected by the spread of the scale of emotional intelligence, the self-efficacy and the adversity quotient that have done the validity and relibility testing first. The data obtained is further analyzed using bergmated regression analysis techniques. The study indicates that emotional intelligence contributes to the development of self-efficacy and adversity quotient of teenager by seeing $R$ square's value indicate a number of 0.636 meaning $63.3 \%$ of emotional intelligence to the self-efficacy and adversity quotient of teenager, while another $36.6 \%$ are affected by other factors not addressed in this research.
\end{abstract}

Keywords:Emotional Intelligence; Self Efficacy; Adversity Quotient;Teenager

\begin{abstract}
AbstrakPenelitian ini bertujuan untuk mengetahui kontribusi kecerdasan emosi terhadap efikasi diri dan adversity quotient remaja.Desain penelitian ini menggunakan rancangan causal relationship study. Subjek dalam penelitian ini merupakan remaja yang duduk di bangku SMP yang berjumlah 60 subjek. Data dikumpulkan dengan cara menyebarkan skala skala kecerdasan emosi, skala efikasi diri dan skala adversity quotientyang telah dilakukan uji validitas dan uji reliabilitasnya terlebih dahulu. Selanjutnya data yang diperoleh dianalisis dengan menggunakan teknik analisis regresi linear berganda. Hasil penelitian ini menunjukkan bahwa kecerdasan emosi memiliki kontribusi terhadap perkembangan efikasi diri dan adversity quotient remaja dengan melihat nilai $\mathrm{R}$ square menunjukkan angka sebesar 0,636 yang artinya sebesar $63,6 \%$ kecerdasan emosi memberikan pengaruh terhadap perkembangan efikasi diri dan adversity quotien remaja sedangkan 36,6 \% lainnya dipengaruhi oleh faktor lain yang tidak dibahas dalam penelitian ini.
\end{abstract}

Kata kunci:Kecerdasan Emosi; Efikasi Diri; Adversity Quotient;Remaja

\section{PENDAHULUAN}

Masa remaja merupakan salah satu masa perkembangan yang akan dilalui oleh setiap individu. Menurut Hurlock sebagaimana dikutip oleh (Fitri et al., 2018) masa remaja merupakan periode dimana individu mampu mencapai kematangan mental, emosional, sosial, fisik dan pola peralihan dari masa kanak-kanak menuju dewasa. Menurut Feldman, sebagaimana dikutip oleh (Aliza, 2015) masa remaja merupakan masa dimana individu mengalami peralihan dari anak-anak menuju masa dewasa, masa pemberian kesempatan untuk tumbuh dalam berbagai dimensi, seperti fisik, harga diri, perilaku, kompetensi kognitif dan sosial biologis serta keintiman.

Dalam penelitian Pramana dan Ni Wayan Sukmawati, berdasarkan data dari WHO pada tahun 2010, Indonesia tercatat memiliki angka 
kematian akibat bunuh diri sebanyak 1,6\% $1,8 \%$ setiap 100.000 jiwa. Selain itu data survey nasional juga menyebutkan bahwa terdapat $27 \%$ ide bunuh diri dilakukan oleh peserta didik tingkat lanjut. Pemicu remaja tersebut melakukan bunuh diri disebabkan karena adanya gangguan mood yang mereka rasakan, gejala gangguan kognitif, gangguan pada fisik dan gangguan kecemasan yang kerap dirasakan (Pramana et al., 2014). Selain itu, adanya era revolusi industri 4.0 yang berkembang kian pesat juga dapat menjadi stressor tersendiri bagi remaja. Karena pada usia remaja yang berada pada tahap emosi yang meluap-luap, kemampuan daya juang yang masih memerlukan bimbingan dan ketidakmampuan remaja dalam mengatasi permasalahannya sendiri akan mengantar mereka pada kondisi yang tidak seimbang antara harapan dan kenyataan

Casmini (Wulandari et al., 2017) menyebutkan kecerdasan emosi adalah suatu kecakapan dalam mengelola emosi secara efektif untuk mencapai tujuan, membina ikatan yang produktif dan menggapai kesuksesan. Menurut Goleman (Riyadi, 2015) kecerdasan emosi merupakan salah satu keahlian seorang individu dalam mengetahui perasaannya sendiri, mempunyai kesanggupan untuk memberikan motivasi pada dirinya sendiri dan mampu membina hubungan yang baik dengan sesamanya. Lebih lanjut lagi (Mahmudi \& Suroso, 2014)menyebutkan efikasi diri adalah suatu kepercayaan yang sudah tertanam dalam diri individu terhadap kemampuannya ketika menyelesaikan suatu permasalahan ataupun tugas akademik secara sadar dan yakin bahwa apa yang diinginkan akan berhasil dicapai Bandura juga menyebutkan bahwa efikasi diri merupakan keyakinan dari dalam diri individu terkait dengan kemampuannya dalam menjalankan dan menyudahi tugas ataupun halhal yang terjadi di lingkungan sekitarnya (Mahmudi \& Suroso, 2014). Adapun aspekaspek dari efikasi diri menurut Bandura dalam (Prasetyo, 2016) meliputi magnitude, generality dan strength. Sehingga untuk menopang perkembangan remaja diperlukan keterampilan untuk mengatasi permasalahan yang dihadapi baik permasalahan dari dalam ataupun dari luar dirinya, salah satu keterampilan yang dibutuhkan adalah adversity quotient.

Adversity quotient menurut pendapat (Kusumawati, 2018) merupakan suatu kecerdasan dalam mengatasi permasalahan dan hambatan yang dialami oleh seorang individu. Paul Stoltz (Aryono et al., 2017) menyebutkan bahwa adversity quotient merupakan suatu kemampuan individu dalam mengatasi permasalahan yang dialaminya dan kemampuan individu dalam memprediksi bagaimana dia dapat menyelesaikan persoalan yang dihadapi. Adapun tingkatan adversity quotient menurut Stoltz dalam (Saidah \& Lailatuzzahro, AlAkhda, 2014) meliputi quitters, campers dan climbers. Sehingga, karakter emosi remaja yang cukup unik sangat menarik untuk dikaji lebih dalam terutama berkenaan dengan efikasi diri dan adversity quotient yang diperlukan dalam menghadapi tantangan kehidupannya. 


\section{METODE}

Penelitian ini menggunakan pendekatan kuantitatif, dengan desain causal relationship study. pengambilan data menggunakan metode purposive sampling. Populasi yang digunakan merupakan siswa/i SMP di Yogyakarta, sedangkan sampel yang digunakan dalam penelitian ini ditentukan dengan menggunakan rumus Isaac Michael dengan ketentuan $\mathrm{dk}=1$ dan tingkat kesalahan sebesar 5\%, hasilnya diperoleh sejumlah 60 subjek dengan ktriteria: (1) beragama islam; (2) siswa/I SMP Muhammadiyah 4 Yogyakarta; (3) Dilaporkan memiliki kesulitan mengatasi pemasalahan yang dihadapi berdasarkan data yang terdapat di guru BK; (4) bersedia menjadi subjek penelitian.

Adapun variabel bebas (independent) dalam penelitian ini adalah kecerdasan emosi, sedangkan variabel terikatnya (dependent) yaitu efikasi diri dan adversity quotient. Teknik pengumpulan data dalam penelitian ini yaitu observasi, dokumentasi dan skala sebagai instrumen. Adapun instrument yang digunakan berupa skala kecerdasan emosi berdasarkan konsep kecerdasan emosi Goleman, dengan aspek mengenali emosi diri, mengelola emosi, memotivasi diri, berempati dan membangun hubungan social dengan sesama. Skala efikasi diri disusun berdasarkan teori Albert Bandura, dengan aspek-aspeknya yang meliputi magnitude, generality dan strength. Selanjutnya skala adversity quotient disusun berdasarkan konsep Paul Stoltz dengan tingkatan seperti quitters, campers dan climbers.
Setelah selesai mengumpulkan data penelitian dari para responden, langkah selanjutnya yaitu melakukan olah data, guna memberikan jawaban terhadap rumusan masalah dan hipotesis pada penelitian ini. Teknik analisis data yang digunakan dalam penelitian ini selain uji normalitas ada juga uji analisis deskriptif, uji hipotesis dan uji analisis regresi linier berganda.

Tabel 1. Hasil Analisis Uji Validitas dan Realibilitas Uji Coba Instrument Secara Singkat

\begin{tabular}{|c|c|c|c|}
\hline Instrument & $\begin{array}{c}\text { Cronbach's } \\
\text { Alpha }\end{array}$ & $\begin{array}{c}\text { N of } \\
\text { Items }\end{array}$ & Keterangan \\
\hline $\begin{array}{c}\text { Kecerdasan } \\
\text { emosi }\end{array}$ & 0,937 & 29 & Reliabel \\
\hline $\begin{array}{c}\text { Efikasi diri } \\
\text { Adversity } \\
\text { quotient }\end{array}$ & 0,933 & 29 & Reliabel \\
\hline
\end{tabular}

\section{HASIL DAN PEMBAHASAN}

Salah satu upaya peneliti sebelum melakukan pengambilan data penelitian adalah melakukan uji prasyarat, untuk mengetahui apakah data yang sudah diperoleh sebelumnya sudah layak atau belum. Uji prasyarat yang digunakan dalam penelitian ini yaitu uji normalitas.

\section{Hasil Uji Prasyarat (Uji Normalitas)}

Pengujian normalitas dalam penelitian ini dilakukan guna mengetahui apakah data dari variable bebas dan variable terikat telah berdistribusi normal atau tidak. Uji normalitas yang digunakan dalam penelitian ini menggunakan cara Kolmogorov-Smirnov Test, yang berarti apabila nilai signifikansi $>0,05$ 
maka data berdistribusi normal, sedangkan apabila nilai signifikansinya $<0,05$ maka data tidak berdistribusi secara normal.

Adapun hasil uji normalitas dari data penelitian ini menunjukkan bahwa nilai signifikansi untuk variabel efikasi diri dan kecerdasan emosi sebesar 0,200, dimana nilai tersebut dapat dikatakan > 0,05. Hal ini menunjukkan variable efikasi diri dan kecerdasan emosi berdistribusi normal. Sedangkan untuk variabel adversity quotient nilai signifikansinya menunjukkan nilai sebesar $0,011<0,05$, sehingga dalam uji ini variabel adversity quotient belum berdistribusi normal. Berikut ini merupakan tabel hasilny:

Tabel 2. Hasil Uji Normalitas I

\begin{tabular}{|c|c|c|c|c|}
\hline \multicolumn{5}{|c|}{ One-Sample Kolmogorov-Smirnov Test } \\
\hline & & $\begin{array}{l}\text { Efika } \\
\text { si } \\
\text { Diri }\end{array}$ & $\begin{array}{l}\text { Kecerd } \\
\text { asan } \\
\text { Emosi }\end{array}$ & $\begin{array}{l}\text { Advers } \\
\text { ity } \\
\text { Quouti } \\
\text { ent } \\
\end{array}$ \\
\hline \multicolumn{2}{|l|}{$\mathrm{N}$} & 60 & 60 & 60 \\
\hline \multirow[b]{2}{*}{$\begin{array}{c}\text { Normal } \\
\text { Parameters }\end{array}$} & Mean & 80.42 & 81.70 & 81.77 \\
\hline & $\begin{array}{c}\text { Std. } \\
\text { Deviati } \\
\text { on }\end{array}$ & $\begin{array}{c}10.53 \\
9\end{array}$ & 9.276 & 9.583 \\
\hline \multirow{3}{*}{$\begin{array}{c}\text { Most } \\
\text { Extreme } \\
\text { Differences }\end{array}$} & $\begin{array}{c}\text { Absolu } \\
\text { te }\end{array}$ & .090 & .087 & .132 \\
\hline & $\begin{array}{c}\text { Positiv } \\
\text { e }\end{array}$ & .090 & .087 & .132 \\
\hline & $\begin{array}{l}\text { Negati } \\
\text { ve }\end{array}$ & -.070 & -.056 & -.060 \\
\hline \multicolumn{2}{|c|}{ Test Statistic } & .090 & .087 & .132 \\
\hline \multicolumn{2}{|c|}{ Asymp. Sig. (2-tailed) } & $\begin{array}{c}.200^{c}, \\
d\end{array}$ & $.200^{\mathrm{c}, \mathrm{d}}$ & $.011^{\mathrm{c}}$ \\
\hline \multicolumn{5}{|c|}{ a. Test distribution is Normal. } \\
\hline \multicolumn{5}{|c|}{ b. Calculated from data. } \\
\hline \multicolumn{5}{|c|}{ c. Lilliefors Significance Correction. } \\
\hline \multicolumn{5}{|c|}{ d. This is a lower bound of the true significance. } \\
\hline
\end{tabular}

Langkah selanjutnya yang peneliti lakukan supaya semua variabel dapat berdistribusi normal adalah melakukan penghitungan ulang dengan menggunakan nilai residual dari variabel kecerdasan emosi, efikasi diri dan adversity quotient. Setelah diketahui hasilnya, nilai signifikansi yang diperoleh pada uji normalitas kedua menunjukkan angka sebesar 0,200, dengan demikian angka tersebut $>0,05$. Sehingga kesimpulan dari hasil uji normalitas pada tiga variabel dalam penelitian ini adalah sudah berdistribusi normal dan dapat melanjutkan proses analisis data selanjutnya. Adapun tabel uji normalitas kedua adalah sebagai berikut:

\section{Tabel 3. Uji Normalitas II}

\section{Hasil Uji Analisis Deskriptif}

\begin{tabular}{|c|c|c|}
\hline \multicolumn{3}{|c|}{ One-Sample Kolmogorov-Smirnov Test } \\
\hline & & $\begin{array}{c}\text { Unstandardize } \\
\text { d Residual }\end{array}$ \\
\hline \multicolumn{2}{|l|}{$\mathrm{N}$} & 60 \\
\hline \multirow{2}{*}{$\begin{array}{l}\text { Normal } \\
\text { Parameters }{ }^{\mathrm{a}, \mathrm{b}}\end{array}$} & Mean & .0000000 \\
\hline & $\begin{array}{l}\text { Std. } \\
\text { Deviation }\end{array}$ & 5.59705283 \\
\hline \multirow{3}{*}{$\begin{array}{l}\text { Most Extreme } \\
\text { Differences }\end{array}$} & Absolute & .092 \\
\hline & Positive & .058 \\
\hline & Negative & -.092 \\
\hline \multicolumn{2}{|l|}{ Test Statistic } & .092 \\
\hline \multicolumn{2}{|c|}{ Asymp. Sig. (2-tailed) } & $.200^{\mathrm{c}, \mathrm{d}}$ \\
\hline \multicolumn{3}{|c|}{ a. Test distribution is Normal. } \\
\hline \multicolumn{3}{|c|}{ b. Calculated from data. } \\
\hline \multicolumn{3}{|c|}{ c. Lilliefors Significance Correction. } \\
\hline \multicolumn{3}{|c|}{ d. This is a lower bound of the true significance. } \\
\hline
\end{tabular}

Uji analisis deskriptif dalam penelitian ini digunakan sebagai upaya peneliti dalam mendapatkan hasil deskriptif statistik dari data yang telah diperoleh. Dalam melakukan uji analisis deskriptif pada penelitian ini, peneliti dibantu dengan aplikasi Ms. Excel 2016 dan SPSS 24 for Windows.

\section{Deskripsi Tingkat Kecerdasan Emosi Remaja}

Berdasarkan data yang telah diperoleh diketahui bahwa frekuensi dan prosentase tingkat kecerdasan emosi remaja di SMP Muhammadiyah 4 Yogyakarta, sebagian besar 
berada pada kategori sedang. Hal ini dapat diketahui dengan rincian sebagai berikut: pada kategori tinggi prosentase yang diperoleh sebesar 15\% dengan frekuensi siswa sebanyak 9 anak, 68\% berada pada kategori sedang dengan frekuensi siswa sebanyak 41 anak dan terdapat $17 \%$ berada pada kategori rendah dengan frekuensi siswa sebanyak 10 anak.

\section{Grafik 1. Kategori Tingkat Kecerdasan}

\section{Emosi}

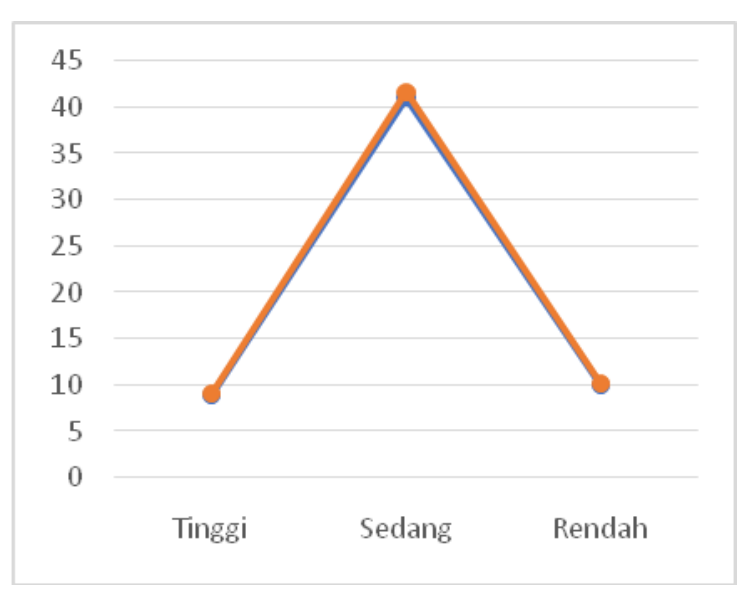

\section{Deskripsi Tingkat Efikasi Diri Remaja}

Berdasarkan data yang telah diperoleh diketahui bahwa frekuensi dan prosentase tingkat efikasi diri remaja di SMP Muhammadiyah 4 Yogyakarta, sebagian besar berada pada kategori sedang. Hal ini dapat diketahui dengan rincian sebagai berikut: pada kategori tinggi prosentase yang diperoleh sebesar $15 \%$ dengan frekuensi siswa sebanyak 9 anak, $73 \%$ berada pada kategori sedang dengan frekuensi siswa sebanyak 44 anak dan terdapat $12 \%$ berada pada kategori rendah dengan frekuensi siswa sebanyak 7 anak.

\section{Grafik 2. Kategori Tingkat Efikasi Diri}

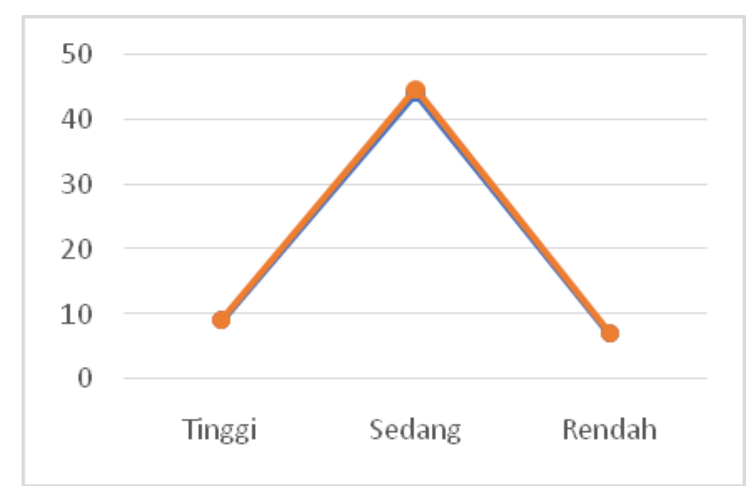

\section{Deskripsi Tingkat Adversity Quotient Remaja}

Berdasarkan data yang telah diperoleh diketahui bahwa frekuensi dan prosentase tingkat adversity quotient remaja di SMP Muhammadiyah 4 Yogyakarta, sebagian besar berada pada kategori sedang. Hal ini dapat diketahui dengan rincian sebagai berikut: pada kategori tinggi prosentase yang diperoleh sebesar $15 \%$ dengan frekuensi siswa sebanyak 9 anak, 63\% berada pada kategori sedang dengan frekuensi siswa sebanyak 38 anak dan terdapat $22 \%$ berada pada kategori rendah dengan frekuensi siswa sebanyak 13 anak.

\section{Grafik 3. Kategori Tingkat Adversity}

\section{Quotient}

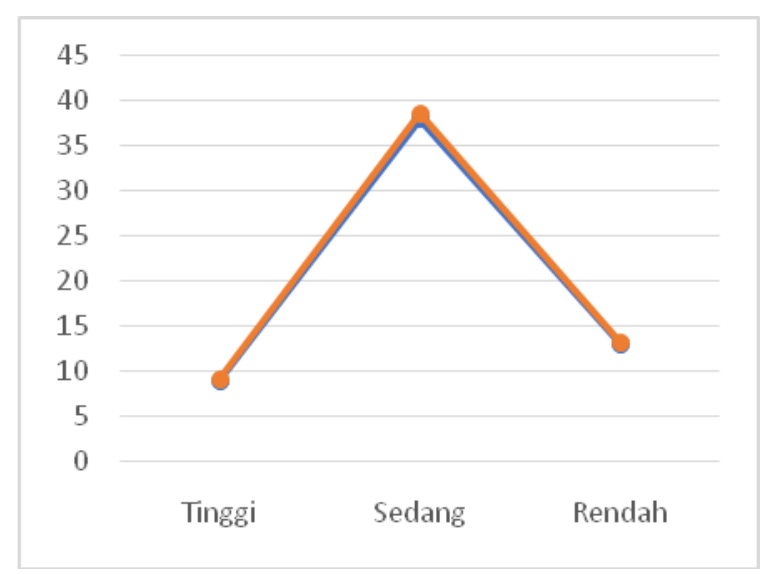




\section{Hasil Uji Hipotesis}

\section{Hasil Uji Hipotesis Pengaruh Kecerdasan}

Emosi Terhadap Efikasi Diri dan Adversity

\section{Quotient Remaja}

Hasil analisis data yang diperoleh menunjukkan angka $\mathrm{R}$ sebesar 0,797 dengan taraf signifikansi menunjukkan nilai $0,000<$ 0,05, artinya Ha diterima dan Ho ditolak. Dengan kata lain, dapat dikatakan bahwa variabel kecerdasan emosi memiliki pengaruh yang signifikan terhadap efikasi diri dan adversity quotient remaja di SMP Muhammadiyah 4 Yogyakarta. Selain itu berdasarkan data yang diperoleh, diketahui terdapat nilai $\mathrm{R}$ square sebesar 0,636 . Artinya $63,6 \%$ kecerdasan emosi berpengaruh terhadap efikasi diri dan adversity quotient remaja. Sedangkan 36,4\% lainnya dipengaruhi faktor lain yang tidak terdapat dalam peneltian ini.

\section{Hasil Uji Hipotesis Pengaruh Kecerdasan}

\section{Emosi Terhadap Efikasi Diri Remaja}

Hasil analisis data yang diperoleh menunjukkan angka $\mathrm{R}$ sebesar 0,647 dengan taraf signifikansi menunjukkan nilai $0,000<$ 0,05, artinya Ha diterima dan Ho ditolak. Dengan kata lain, dapat dikatakan bahwa variabel kecerdasan emosi memiliki pengaruh yang signifikan terhadap efikasi diri remaja di SMP Muhammadiyah 4 Yogyakarta. Selain itu berdasarkan data yang diperoleh, diketahui terdapat nilai $\mathrm{R}$ square sebesar 0,419 . Artinya 41,9\% kecerdasan emosi berpengaruh terhadap efikasi diri remaja. Sedangkan $58,1 \%$ lainnya dipengaruhi faktor lain yang tidak terdapat dalam peneltian ini

\section{Hasil Uji Hipotesis Pengaruh Kecerdasan Emosi Terhadap Adversity Quotient Remaja}

Hasil analisis data yang diperoleh menunjukkan angka $\mathrm{R}$ sebesar 0,792 dengan taraf signifikansi menunjukkan nilai $0,000<$ 0,05, artinya $\mathrm{Ha}$ diterima dan Ho ditolak. Dengan kata lain, dapat dikatakan bahwa variabel kecerdasan emosi memiliki pengaruh yang signifikan terhadap adversity quotient remaja di SMP Muhammadiyah 4 Yogyakarta. Selain itu berdasarkan data yang diperoleh, diketahui terdapat nilai $\mathrm{R}$ square sebesar 0,627. Artinya $62,7 \%$ kecerdasan emosi berpengaruh terhadap adversity quotient remaja. Sedangkan $37,3 \%$ lainnya dipengaruhi faktor lain yang tidak terdapat dalam peneltian ini.

\section{PEMBAHASAN}

\section{Pengaruh Kecerdasan Emosi Terhadap}

\section{Efikasi Diri dan Adversity Quotient Remaja}

\section{SMP Muhammadiyah 4 Yogyakarta}

Stoltz (2009, dalam Santos 2012) sebagaimana dikutip oleh(Wibowo et al., 2015)mengemukakan bahwa individu yang mempunyai tingkat adversity quotient tinggi, akan memiliki daya tahan yang lebih baik dan efektif ketika dihadapkan dengan persoalan dan hambatan ketika mengerjakan tugas. Hal ini menunjukkan bahwa semakin tinggi tingkat adversity quotient dan efikasi diri, maka semakin tinggi pula kemampuan dan performa individu tersebut dalam menerima dan menghadapi tantangan yang dihadapinya. 
Berdasarkan penelitian yang dilakukan oleh (Wibowo et al., 2015) dijelaskan bahwa siswa dengan tingkat kecerdasan emosi tinggi akan memiliki kebiasaan belajar yang baik, sedangkan sisa dengan tingkat kecerdasan emosi yang rendah akan lebih cenderung memilih melakukan hal-hal yang tidak berkaitan dengan pencapaian akademisnya. Sejalan dengan hal tersebut Parker dan Shipley dkk (2010, dalam Wibowo, 2015) juga mengemukakan pendapat bahwa kecerdasan emosi merupakan salah satu penentu kesuksesan dari pencapaian seorang individu.

\section{Pengaruh Kecerdasan Emosi Terhadap}

Efikasi Diri Remaja SMP Muhammadiyah 4 Yogyakarta

Kecerdasan emosi memiliki pengaruh yang positif terhadap efikasi diri, hal ini diperkuat oleh pendapat (Hulu \& Minauli, 2015)yang menyatakan bahwa kecerdasan emosi tinggi dapat meningkatkan efikasi diri pada individu sehingga mereka mampu menggapai tujuan hidupnya. Sedangkan individu yang memiliki tingkat kecerdasan emosi dan efikasi diri rendah, akan lebih sulit dalam mencapai tujuan dan impiannya. Hal ini sejalan dengan teori yang dikemukakan oleh (Wigati, 2018) dalam penelitian, yang menyebutkan bahwa terdapat hubungan yang signifikan dan positif antara kecerdasan emosi dengan efikasi diri. Semakin tinggi kecerdasan emosi seorang individu, maka tingkat efikasi diri nya akan semakin meningkat dan begitu juga sebaliknya.
Bandura dalam (Wibowo et al., 2015) menjelaskan bahwa efikasi diri merupakan suatu hal yang dapat mempengaruhi tindakan apa yang akan dipilih oleh individu dalam menggapai impiannya dan seberapa besar usaha yang akan diberikan dalam upaya pencapaian tersebut. Bandura juga mengatakan bahwa siswa dengan efikasi diri yang tinggi akan lebih mampu mengembangkan sikap yang prososial, fleksibel dan selalu ingin mencoba hal baru dengan lingkungannya. Berdasarkan penelitian Alwisol (2004, dalamNuraini, 2018) efikasi diri atau keyakinan yang berada di dalam diri individu masih mampu mengalami perubahan, hal tersebut dikarenakan efikasi diri individu yang masih rendah sehingga memiliki keterbatasan pengalaman ataupun kurangnya sumber informasi di masa lalu, sehingga individu tersebut tidak memiliki solusi lain dalam mengatasi persoalan dan masalah yang dihadapinya. Oleh karena itu, ketika efikasi diri seorang individu tinggi, maka hal tersebut dapat mempengaruhi aspek lain dalam kehidupannya menjadi lebih baik lagi. Sedangkan apabila efikasi diri yang dimiliki individu itu rendah maka akan ada kesulitan dan hambatan yang terasa lebih banyak lagi ketika menghadapi suatu persoalan.

\section{Pengaruh Kecerdasan Emosi Terhadap}

\section{Adversity Quotient Remaja SMP}

\section{Muhammadiyah 4 Yogyakarta}

Kecerdasan emosional memiliki pengaruh yang signifikan terhadap adversity quotient hal ini diperkuat dengan hasil penelitian (Hanifa, 2017) yang menyatakan bahwa kecerdasan 
emosi dan adversity quotient memiliki hubungan yang kuat dan sangat signifikan terhadap kecemasan menghadapi dunia kerja pada siswa SMK Muhammadiyah 1 Samarinda. Kecerdasan emosi dan adversity quotient yang dimiliki oleh individu akan mampu menimbulkan perilaku berpikir kritis dan rasional serta mempunyai kesungguhan dalam menghadapi beragam permaslahan dan hambatan yang kemudian membuat individu tersebut pantang menyerah(Hanifa, 2017).Putra et al., (2016) menyatakan bahwa tingkat adversity quotient yang tinggi merupakan salah satu faktor penting yang harus dimiliki oleh setiap individu, supaya mereka tetap memiliki tujuan tentang masa yang akan datang dalam kehidupan. Rahmawati (2006, dalamPutra et al., 2016) juga mengemukakan bahwa semakin tinggi tingkat adversity quotient remaja, maka akan semakin rendah kecemasan tentang masa depan, yang akan mereka jalani.

\section{KESIMPULAN}

Berdasarkan hasil analisis data yang sudah dilakukan pada penelitian ini, dapat disimpulkan bahwa: (1) Rata-rata siswa SMP Muhammadiyah 4 Yogyakarta memiliki kecerdasan emosi, efikasi diri dan adversity quotient pada kategori sedang; (2) Ada pengaruh yang signifikan antara kecerdasan emosi terhadap efikasi diri dan adversity quotient remaja siswa/i SMP Muhammadiyah 4 Yogyakarta, dengan nilai signifikansi 0,000< 0,05 dan nilai $\mathrm{R}$ square sebesar 0,636; (3) Ada pengaruh yang signifikan antara kecerdasan emosi terhadap efikasi dirisiswa/i SMP Muhammadiyah 4 Yogyakarta, dengan nilai signifikansi sebesar $0,000<0,05$ dan nilai $R$ square sebesar 0,419 ; (4) Ada pengaruh yang signifikan antara kecerdasan emosi terhadap adversity quotient siswa/i SMP Muhammadiyah 4 Yogyakarta, dengan nilai signifikansi sebesar $0,000<0,05$ dan nilai $\mathrm{R}$ square sebesar 0,627.

\section{DAFTAR RUJUKAN}

Aliza, N. (2015). Pengaruh Terapi Psikospiritual Untuk Meningkatkan Kesejahteraan Psikologis Remaja. Empathy, 3(2), 241594.

Aryono, S. Y., Machmuroch, \& Karyanta, N. A. (2017). Hubungan antara Adversity Quotient dan Kematangan Emosi dengan Toleransi terhadap Stres pada Mahasiswa Pecinta Alam Universitas Sebelas Maret.Jurnal Wacana,9(18), 12-27. http://jurnalwacana.psikologi.fk.uns.ac.id/ index.php/wacana/article/view/108

Fitri, E., Zola, N., \& Ifdil, I. (2018). Profil Kepercayaan Diri Remaja serta FaktorFaktor yang Mempengaruhi. JPPI (Jurnal Penelitian Pendidikan Indonesia), 4(1), 1. https://doi.org/10.29210/02017182

Hanifa, Y. (2017). Hubungan antara emotional quotient dan adversity quotient dengan kecemasan menghadapi dunia kerja pada siswa SMK. Psikoborneo, 5(1), 43-55.

Hulu, T., \& Minauli, I. (2015). Hubungan Antara Kecerdasan Emosi dan Efikasi Diri Dengan Prestasi Belajar. Psikologi, $5(2)$, $50-56$ http://ojs.uma.ac.id/index.php/analitika/art icle/view/785

Kusumawati, E. D. (2018). Pengaruh Adversity Quotient, Regulasi Diri Dan Efikasi Diri Terhadap Motivasi Berprestasi Siswa Kko Smp Negeri 13 Yogyakarta.Jurnal Pendidikan Agama Islam, 14(1), 131-165. https://doi.org/10.14421/jpai.2017.141-08 
Mahmudi, M. H., \& Suroso, S. (2014). Efikasi Diri, Dukungan Sosial dan Penyesuaian Diri Dalam Belajar.Persona:Jurnal Psikologi Indonesia,3(02), 183-194. https://doi.org/10.30996/persona.v3i02.38 2

Nuraini, Q. (2018). Diri Terhadap Stres Akademik Siswa Full Day.

Pramana, R. D., Wayan, N., \& Puspitadewi, S. (2014). Hubungan antara Kecerdasan Emosi dan Tingkat Depresi dengan Ide Bunuh Diri. Character,02, 1-6.

Prasetyo, Y. (2016). Efikasi Diri, Kematangan Emosi dan Problem Focus Coping. Persona:Jurnal Psikologi Indonesia, 5(02), 181-186. https://doi.org/10.30996/persona.v5i02.73 6

Putra, M. R. G., Hidayati, N. O., \& Nurhidayah, I. (2016). Hubungan Motivasi Berprestasi Dengan Adversity Quotient Warga Binaan Remaja Di Lpka Kelas Ii Sukamiskin Bandung.Jurnal Pendidikan Keperawatan Indonesia, $2(1), \quad 52$. https://doi.org/10.17509/jpki.v2i1.2853

Riyadi, I. (2015). Integrasi Nilai-Nilai Kecerdasan Emosional Dalam Kurikulum Pendidikan Agama Islam Di Sma: Perspektif Daniel Goleman.HUNAFA: Jurnal Studia Islamika, 12(1), 141. https://doi.org/10.24239/jsi.v12i1.376.141 $-163$

Saidah, S., \& Lailatuzzahro, Al-Akhda, A. (2014). Hubungan self-efficacy dan adversity quotient (AQ). Jurnal Psikologi,2(2), 54-61.

Wibowo, M. W., Psikologi, P. S., \& Malang, U. G. (2015). Hubungan Antara Kecerdasan Emosi , Adversity Quotient Dan Efikasi Diri Pada Siswa Kelas Xii Madrasah Aliyah Negeri 1 Magelang 10(2), 186-200.

Wigati, T. W. (2018). Hubungan Kecerdasan Emosional Dan Kompetensi Profesional Dengan Efikasi Diri Guru Smp Di Kecamatan Bandar Sribhawono
Kabupaten Lampung Timur. Jurnal Lentera Pendidikan Pusat Penelitian LPPM UM METRO, Vol. 3. No(1), 99109.

Wulandari, D., Yulianeu, \& Mukeri Warso, M. (2017). Pengaruh Kecerdasan Emosional Terhadap Stres Kerja Melalui Efikasi Diri (Studi Kasus Pada Sekolah Luar Biasa Negeri Semarang).Journal of Management, 3(3). jurnal.unpand.ac.id 